\title{
The Importance of GLWamide Neuropeptides in Cnidarian Development and Physiology
}

\author{
Toshio Takahashi ${ }^{1}$ and Masayuki Hatta ${ }^{2}$ \\ ${ }^{1}$ Suntory Foundation for Life Sciences, Bioorganic Research Institute, 1-1-1 Wakayamadai, Shimamoto, \\ Mishima, Osaka 618-8503, Japan \\ ${ }^{2}$ Department of Biology, Ochanomizu University, Bunkyo-ku, Tokyo 112-8610, Japan
}

Correspondence should be addressed to Toshio Takahashi, takahashi@sunbor.or.jp

Received 14 June 2011; Accepted 22 August 2011

Academic Editor: Dinkar Sahal

Copyright ( 2011 T. Takahashi and M. Hatta. This is an open access article distributed under the Creative Commons Attribution License, which permits unrestricted use, distribution, and reproduction in any medium, provided the original work is properly cited.

The peptide-signaling molecules ( $<50$ amino acid residues) occur in a wide variety of invertebrate and vertebrate organisms, playing pivotal roles in physiological, endocrine, and developmental processes. While some of these peptides display similar structures in mammals and invertebrates, others differ with respect to their structure and function in a species-specific manner. Such a conservation of basic structure and function implies that many peptide-signaling molecules arose very early in the evolutionary history of some taxa, while species-specific characteristics led us to suggest that they also acquire the ability to evolve in response to specific environmental conditions. In this paper, we describe GLWamide-family peptides that function as signaling molecules in the process of muscle contraction, metamorphosis, and settlement in cnidarians. The peptides are produced by neurons and are therefore referred to as neuropeptides. We discuss the importance of the neuropeptides in both developmental and physiological processes in a subset of hydrozoans, as well as the potential use as a seed compound in drug development and aspects related to the protection of corals.

\section{Introduction}

Peptide-signaling molecules ( $<50$ amino acid residues) have been found in a wide variety of organisms and many are known to play important roles in regulating physiological processes in both vertebrates and invertebrates. For example, peptide-signaling molecules act as neurohormones in the endocrine system and as neurotransmitters or neuromodulators in the nervous system. In addition, individual neuropeptides have been found to be multifunctional and may be involved in the immune response, developmental processes, and physiological processes within a single organism. The action of these peptides has been found to be spatiotemporally regulated, which ensures that the timing and pattern of development proceed correctly and that viability is maintained.

Among metazoan organisms, the freshwater cnidarian Hydra (Figure 1(a)) has one of the most primitive nervous systems. The nervous system of the Hydra is gener- ally regarded as a diffuse, net-like structure that extends throughout the animal (Figure 1(b)). This "nerve net" is composed of two morphologically distinct cell types, ganglion cells, and sensory cells [1]. To date, a variety of neuropeptides have been identified in Cnidaria. For example, the GLWamide-family peptides that have been isolated from the sea anemone, Anthopleura elegantissima [2], and Hydra magnipapillata [3] have been shown to induce the metamorphosis of Hydractinia serrata planula larvae into polyps. In Hydra, GLWamides induce detachment of the bud from a parental polyp [3]. Budding is the form of asexual reproduction in this animal. The neuropeptide, Hym-355 that Hym are tentatively named from Hydra magnipapillata, enhances neuronal differentiation by inducing multipotent interstitial stem cells to enter the neuron differentiation pathway [4]. A myoactive neuropeptide, Hym-176, specifically and reversibly induces contraction of the ectodermal muscles of the body column, in particular in the peduncle region of Hydra [5]. In addition, one of the Hydra-RFamides, 


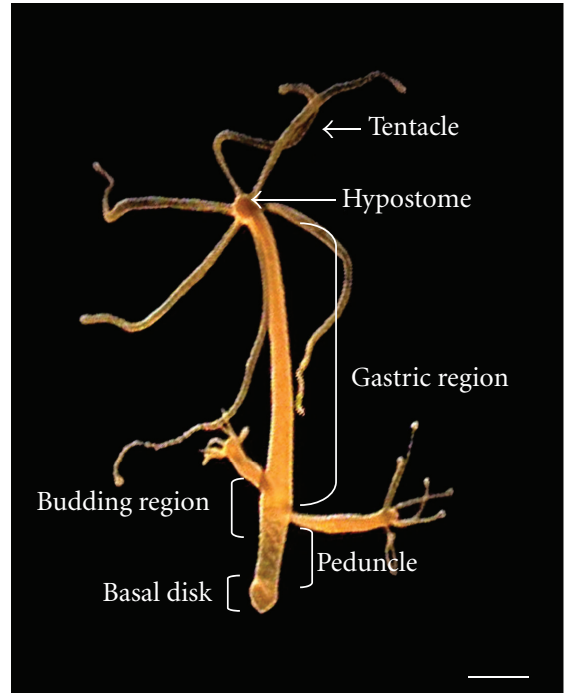

(a)

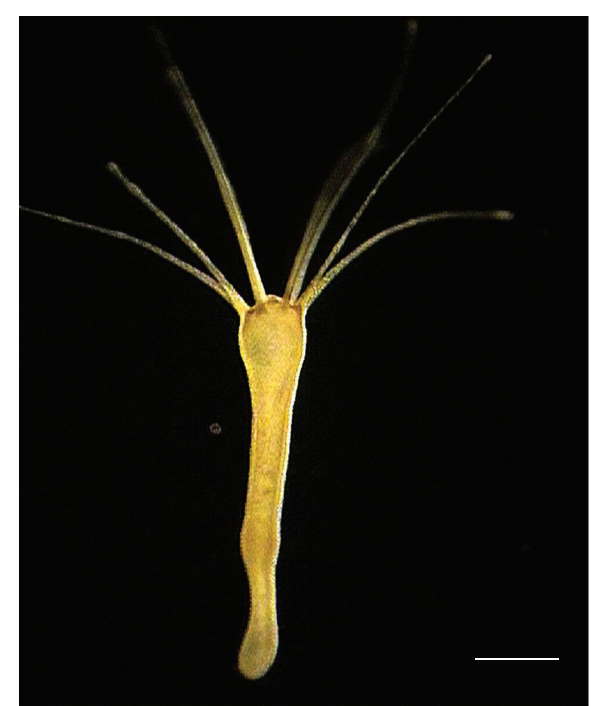

(c)

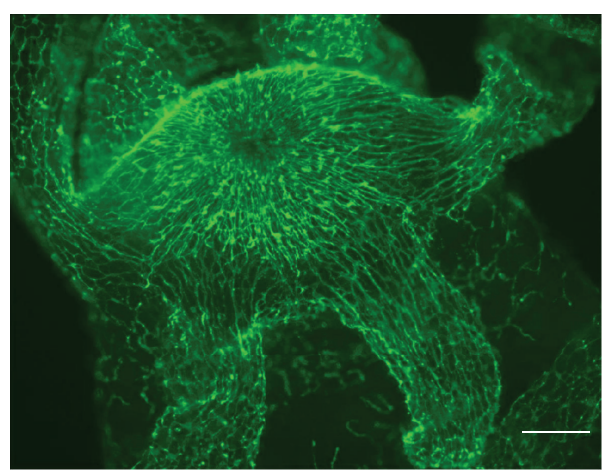

(b)

Figure 1: Types of hydra. (a) Normal Hydra. (b) Head of Hydra. Nerve cells are visualized by indirect immunofluorescence using an antiRFamide antibody. (c) Epithelial Hydra. Scale bars represent $2 \mathrm{~mm}$ (a and c) and $100 \mu \mathrm{m}$ (b), respectively.

Hydra-RFamide III, has a dose-dependent effect on pumping of the peduncle, which is considered to be the equivalent of the heart of higher organisms [6]. More recently, two members of a novel neuropeptide family (FRamides) that form part of the same precursor were shown to have opposite myoactive functions in epithelial Hydra (Figure 1(c)), which are Hydra that have no nerve cells [7].

GLWamide-family peptides have characteristic structural features in their $\mathrm{N}$ - and C-terminal regions. For example, the peptides all share a GLWamide motif at their C-termini, and seven of the GLWamide peptides isolated from Hydra were found to have a proline residue at the second position (XPro) or at the second and third positions (X-Pro-Pro) of their $\mathrm{N}$-terminal regions (Table 1). Metamorphosin A (MMA), isolated from Anthopleura, has a pyroglutamyl residue at the $\mathrm{N}$-terminus. Interestingly, both of these $\mathrm{N}$-terminal structures confer resistance to aminopeptidase digestion [8].

Recently, one of the Hydra-derived GLWamide-family neuropeptides, Hym-248, was demonstrated to induce both settlement and metamorphosis in cultured planulae of nine Pacific Acropora species and mixed Acropora coral slicks with remarkable consistency $[9,10]$. Furthermore, planulae of the Caribbean coral Acropora palmata were induced to settle by the exogenous application of Hym-248 [11]. These observations suggest that the underlying neurotransmission signal, which is induced by external cues, is conserved and can be exogenously manipulated beyond hydrozoans.

In this paper, we describe GLWamide-family peptides that function as signaling molecules in muscle contraction, metamorphosis, and settlement in cnidarians including corals and polyps. We also discuss the importance of the neuropeptides in the development and physiology of a subset of hydrozoans and also their potential role as seed compounds in drug discovery and aspects related to the protection of corals.

\section{Induction of Metamorphosis in Planula Larvae of the Marine Hydrozoan Hydractinia}

Species of the genus Hydractinia are colonial and usually live on snail shells inhabited by hermit crabs (Figure 2(a)). In their life cycle, there is only a planula larval stage with no 
TABLE 1: Structure and function of GLWamide-family peptides isolated from Hydra and Anthopleura.

\begin{tabular}{lcc}
\hline Name & Structure & Function \\
\hline Hym-53 & NPYPGLWamide & Myoactivity and Metamorphosis \\
Hym-54 & GPMTGLWamide & Myoactivity and Metamorphosis \\
Hym-248 & EPLPIGLWamide & Myoactivity, Metamorphosis, and Settlement \\
Hym-249 & KPIPGLWamide & Myoactivity and Metamorphosis \\
Hym-331 & GPPPGLWamide & Myoactivity and Metamorphosis \\
Hym-338 & GPPh PGLWamide & Myoactivity and Metamorphosis \\
Hym-370 & KPNAYKGKLPIGLWamide & Myoactivity and Metamorphosis \\
MMA & pQQPGLWamide & Myoactivity and Metamorphosis \\
\hline
\end{tabular}

${ }^{\mathrm{h}} \mathrm{P}$ : hydroxyproline. pQ: pyroglutamate.

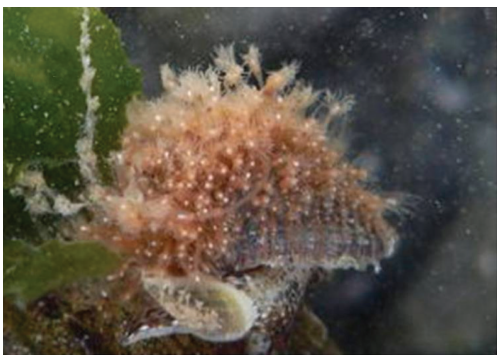

(a)

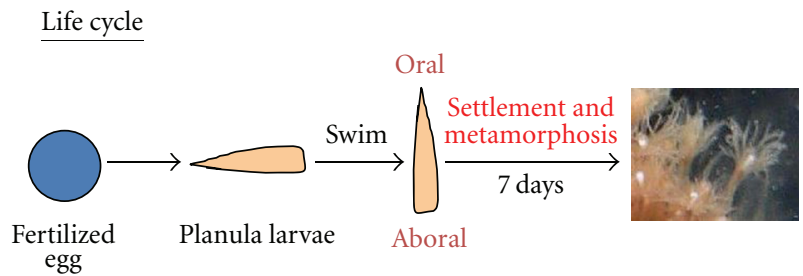

(b)

Figure 2: Hydractinia. (a) Hydractinia epiconcha on a hermit crab. (b) Life cycle of Hydractinia.

medusa stage (Figure 2(b)). Upon settling, the planula larvae undergo metamorphosis and develop into polyps after approximately one week. Leitz et al. [2] isolated the neuropeptide MMA from the sea anemone Anthopleura elegantissima and showed that MMA induces the metamorphosis of planula larvae of the marine hydrozoan Hydractinia echinata into polyps (Table 1). Their findings demonstrated that, in addition to playing roles as neurotransmitters and neuromodulators, some cnidarian neuropeptides function as neurohormones and control developmental processes. We independently isolated seven peptides belonging to the GLWamide family from Hydra magnipapillata that shared a GLWamide motif in their C-terminal region (Table 1) [3, 12].

All neuropeptides are produced and secreted by highly regulated secretion pathways. In general, the precursors of neuropeptides are incorporated into the endoplasmic reticulum as a preprohormone where they are converted into prohormones via the removal of a signal peptide region. These prohormones are then transported to the Golgi apparatus where they undergo posttranslational modification such as endoproteolysis and C-terminal amidation before assuming their final active peptide forms [13]. Leviev et al. cloned the Hydra preprohormone gene that encodes all of the GLWamide peptides that we identified previously (Figure 3) [14].

All of the GLWamide peptides produced by Hydra have the ability to induce the metamorphosis of Hydractinia serrata planula larvae into polyps $[3,12]$. An Nterminal deletion series revealed that a common GLWamide sequence is necessary for the induction of metamorphosis in Hydractinia. However, the precise mechanisms involving the GLWamide peptides in the induction of metamorphosis are not yet clearly understood. Interestingly, larvae can be induced to undergo metamorphosis in response to a chemical signal secreted by environmental bacteria [2]. This chemical signal is most likely received by the sensory neurons of the planula larvae, which then release GLWamide peptides that act on the surrounding epithelial cells and result in a change in the phenotype. However, since hydras develop directly from embryos into adult polyps and have no intermediate larval stage, the precise function of the GLWamide peptides in early embryogenesis in Hydra is thus still an open question.

\section{Myoactivity in Hydra and the Sea Anemone Anthopleura}

Given the absence of a planula larval stage in the life cycle of Hydra, we searched for another function of GLWamide peptides in this genus. Interestingly, we found that all GLWamide peptides induce detachment of the bud from the parental polyp [3]. Briefly, the process of budding is associated with the development of a circular or sphincter muscle in the basal disk late in bud development ( $R$. Campbell, pers. comm.) (Figure 4(a)). Contraction of this sphincter muscle results in the constriction of the basal disk of the bud, thereby "pinching off" the bud from the parent. Tests of myoactivity typically employ epithelial Hydra (Figure 1(c)), which are hydras with no nerve cells or any of the other cells derived from the interstitial stem cell lineage, except gland cells $[15,16]$. Since epithelial Hydra are 


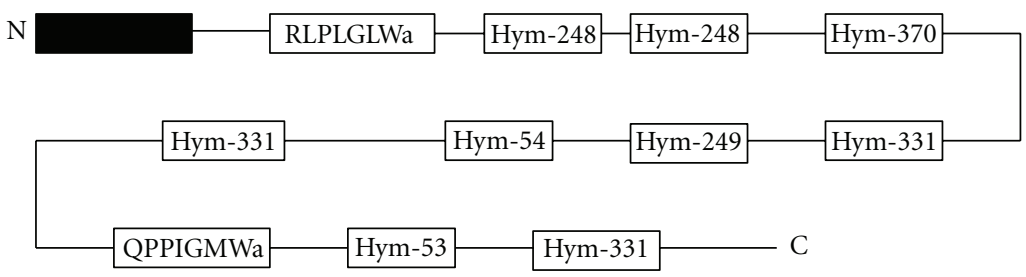

FIGURE 3: Schematic representation of the preprohormone containing a signal sequence (black box) and two putative neuropeptide sequences (RLPLGLWamide and QPPIGMWamide) and unprocessed GLWamide peptides (Hym-53, 54, 248, 249, 331, and 370) in Hydra.

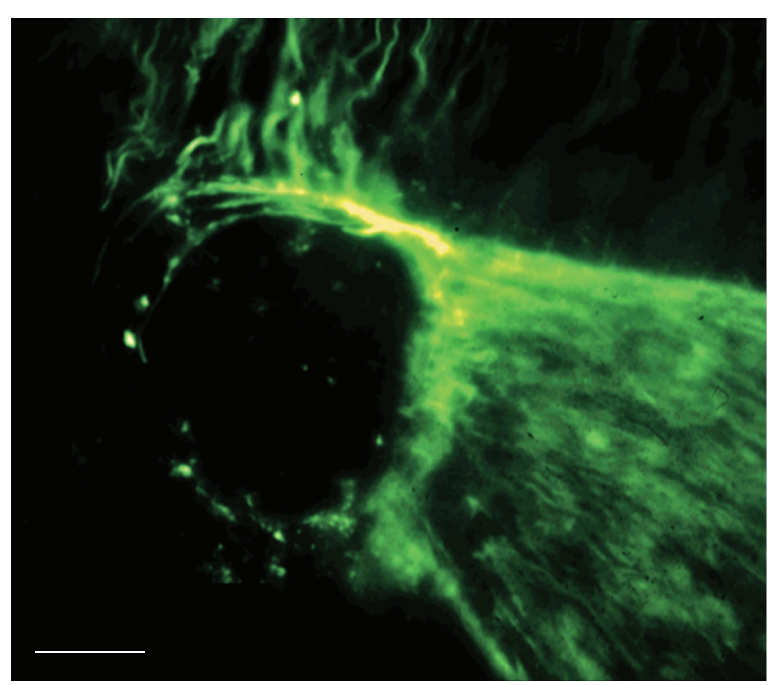

(a)

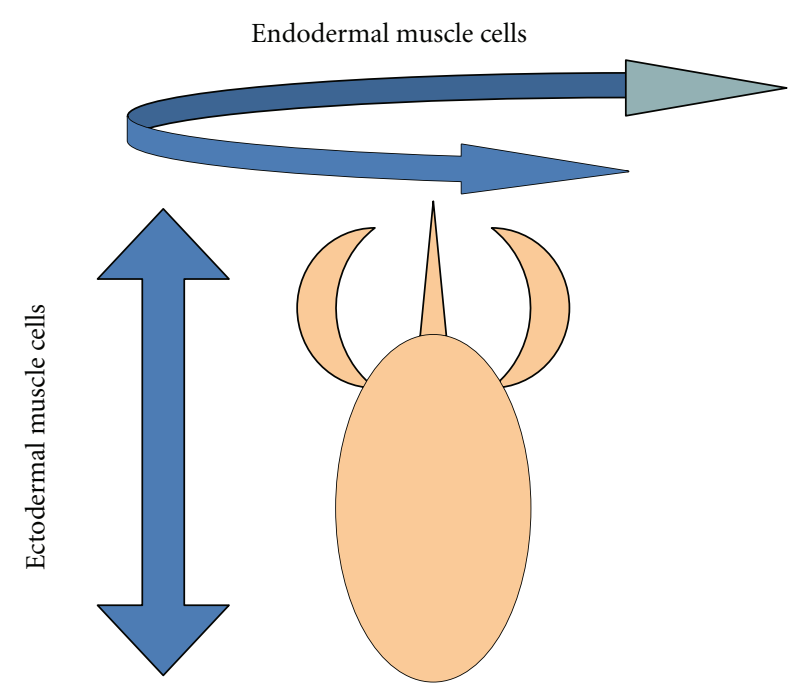

(b)

FIgURE 4: Muscle process in hydra. (a) Sphincter muscle process in bud was stained using antimyosin heavy chain. Scale bar represents $0.5 \mathrm{~mm}$. (b) Muscle processes of ectodermal epithelial cells run longitudinally and those of endodermal epithelial cells run circumferentially.

primarily composed of epithelial muscle cells, the epithelial layer of the Hydra "body" is a homogenous, in vivo muscle preparation that is particularly well suited to examinations of the direct effect of a peptide on muscle cells. A similar effect, that is, induction of bud detachment, was also observed in normal Hydra treated with the peptides.

While elucidating the function of the GLWamide-family peptides, we found that Hym-248 had an unexpected effect on the Hydra body. Specifically, Hym-248 not only induced bud detachment when applied to epithelial Hydra, but also elongated the body column [12]. In Hydra, muscle processes extending from ectodermal and endodermal epithelial cells run perpendicular to each other, with the ectodermal processes oriented along the body column axis and endodermal processes oriented circumferentially (Figure $4(\mathrm{~b}))$. Contraction of the ectodermal muscles results in a shortening of the body column, while contraction of the endodermal muscles, such as that observed in response to Hym-248, results in elongation of the body column. Since Hym-248 has two target muscles (the sphincter and endodermal muscles), it is possible that Hym-248 has two types of receptors: one that is common to all GLWamidefamily peptides and another is specific to Hym-248. In higher organisms, most neuropeptides act as ligands for G- protein-coupled receptors (GPCRs) on target cells. Signaling via GPCR is a major route of cellular communication via the plasma membrane. Identification of both the common receptor of GLWamide-family peptides and the Hym-248specific receptor is currently in progress.

The isolation of MMA from the sea anemone Anthopleura elegantissima implies that GLWamide-family peptides are biologically active in this organism. We found that all GLWamide-family peptides induced contraction of the retractor muscle (RM) in Anthopleura fuscoviridis [12]. The gastric cavity of $A$. fuscoviridis is partitioned by pairs of mesenteries, which are longitudinal extensions of the body wall that are covered by gastrodermal epithelium (Figure 5). The free apical edges of the mesenteries contain the gonads and the filaments, and the RMs are located proximal to these structures (Figure 5(b)), which extend longitudinally from the oral disk to the basal disk on one side of each mesentery (Figure 5). These muscles are the strongest and most well developed in A. fuscoviridis. Immunohistochemical staining with an antibody specific for the GLWamide motif revealed intensely stained nerve cells in the RMs of the sea anemone as well as the nervous system of Hydra [12]. These observations corroborated those of Leitz and coworkers who reported similar findings in Hydra and Hydractinia [17, 18]. Taken 


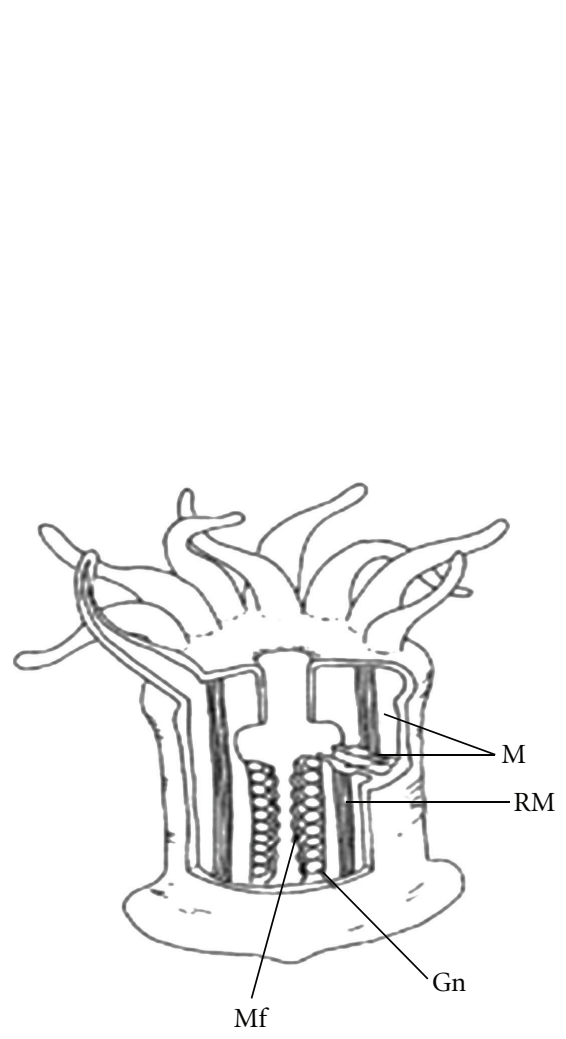

(a)

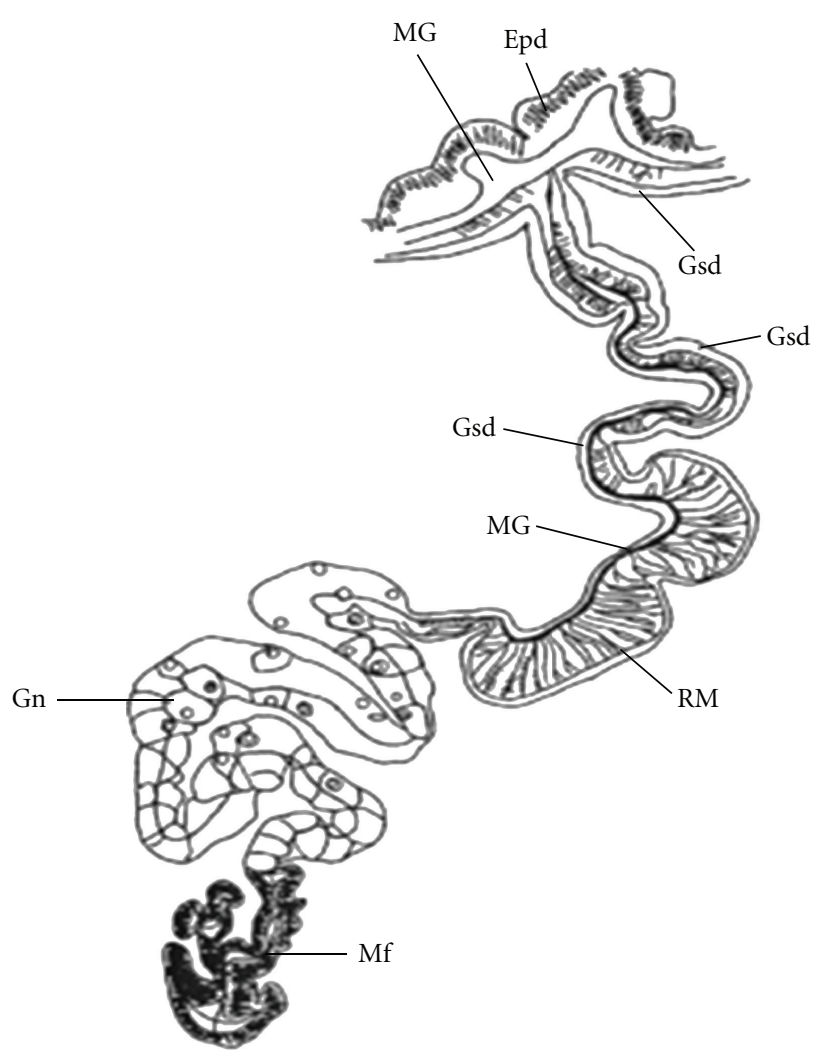

(b)

Figure 5: Schematic diagram of A. fuscoviridis and its retractor muscle. (a) Longitudinal section of the sea anemone showing the paired mesenteries that partition the gastric cavity. The free edge of the mesentery below the pharynx contains the gonads and filaments. The longitudinal retractor muscles are located on one side of the mesentery. (b) Detailed illustration of a cross-section through a mesentery. A mesentery is composed of two gastrodermal layers, one containing the longitudinal retractor muscles. The mesoglea ramifies within the retractor muscles. M, paired mesenteries; RM, retractor muscle; Epd, epidermis (ectoderm); Gsd, gastrodermis (endoderm); MG, mesoglea; Gn, gonad; Mf, mesenterial filament. Comparative Biochemistry and Physiology Part B (2003) 135, 309-324 [12].

together, these findings imply that GLWamide-family peptides act as neurotransmitters or neuromodulators at neuromuscular junctions in Cnidaria.

To determine whether members of the GLWamide family occur in other phyla, we screened a variety of organisms for the GLWamide motif using an anti-GLWamide antibody (Figure 6). In almost all cases, neurons were observed to be immunoreactive (Fujisawa and Koizumi, unpublished observations). While this does not necessarily mean that GLWamide-related peptides are present in these species, it does suggest that, like the RFamide superfamily [19], GLWamide-related peptides are widely distributed throughout the animal kingdom. However, at least in C. elegans, a gene encoding three putative GLWamide peptides exists.

\section{Settlement and Metamorphosis Induction in the Coral Acropora}

Coral reef ecosystems are important components of shallow tropical sea environments. Nonetheless, despite the implementation of a variety of preservation and management initiatives, the effects of direct and indirect anthropogenic activities are destroying coral reefs at an alarming rate. The most conspicuous example of this damage is coral bleaching, which occurs as when the intracellular symbiotic algae (zooxanthellae) of the choral die [20]. Over the last two decades, coral bleaching has increased in frequency, intensity, and spatial extent [21].

In Indo-Pacific reefs, the coral genus Acropora (Figure $7(a))$ consists of major species and coral communities are maintained in large part through recruitment of their larvae. Sexual reproduction in many acroporids occurs via "mass spawning" events, which are characterized by the synchronous release of millions of gametes into the water column by many colonies belonging to multiple species $[22,23]$. The high densities of floating gametes form patches referred to as "slicks" on the ocean surface. The resultant larvae are then dispersed by currents where after they settle on substrates and begin the sedentary part of their life cycle (Figure 7(b)). Despite the large number of larvae produced by these mass spawning events, very few survive the drifting period and only a small proportion are recruited into reef communities. If some of the larvae that would otherwise 


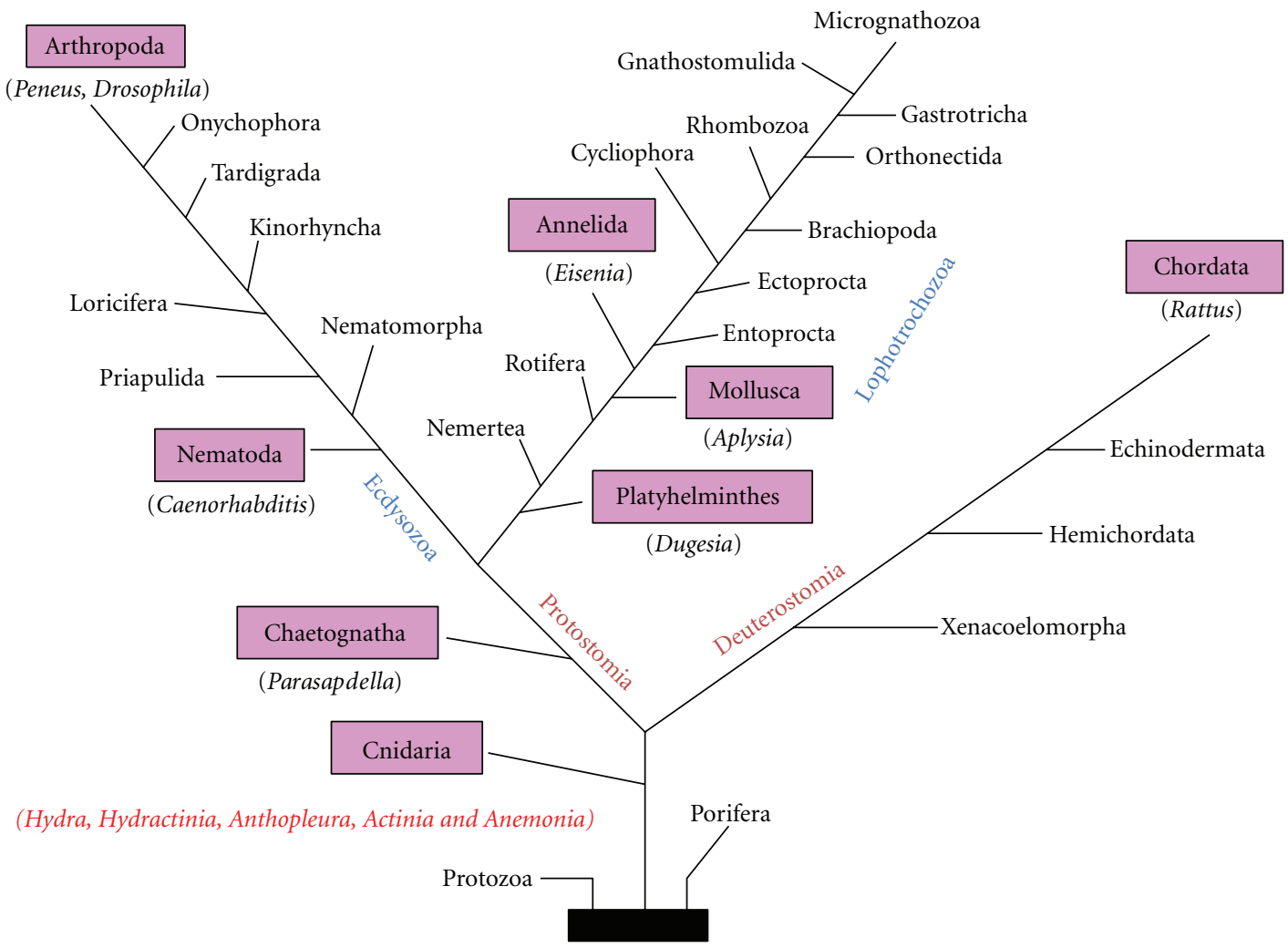

FIgure 6: Phyla with anti-GLWamide antibody-positive neurons. Immunoreactive phyla are colored in pink.

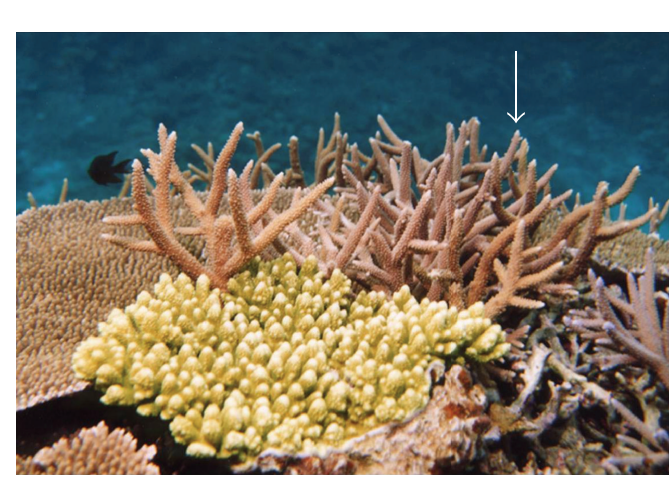

(a)

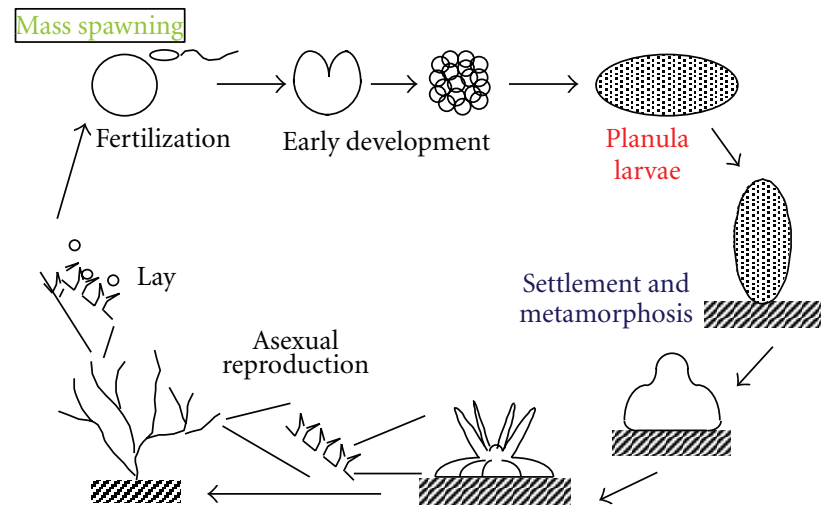

(b)

Figure 7: Appearance and life cycle of Acropora. (a) Acropora spp. (arrow), (b) life cycle of Acropora.

be lost prior to settlement could be collected and cultivated under controlled conditions, they could be used as donors for reef transplantation without damaging existing coral communities.

However, the difficulty associated with such an approach is the lack of a method for controlling the settlement and metamorphosis of Acropora. We recently found that a member of the GLWamide family of peptides, Hym248 , is capable of inducing metamorphosis of acroporid larvae into polyps at high rates (approximately 100\%) [10] and that Acropora planulae responded to the peptide in a concentration-dependent manner [10]. Planulae of the Caribbean coral Acropora palmata were also induced to settle after the exogenous application of Hym-248, with rates of attachment and metamorphosis of planula larvae of six days after fertilization reaching $40-80 \%$ and $100 \%$, respectively [11]. Interestingly, however, Hym-248 was not capable of inducing metamorphosis in other coral genera $[10,11]$. It therefore appears that, in corals, the specificity of ligand recognition by receptors is dependent on the extent to which peptide(s) of particular structures are recognized. However, in Hydractinia, the specificity is less stringent and 
receptors are able to recognize any peptides belonging to the GLWamide family. Since Hym-248 is a surrogate ligand in Acropora, natural ligand(s) that are similar in structure to Hym-248 should be identified.

This is the useful success in inducing metamorphosis of coral larvae in Acropora. Indeed, Hatta and Iwao [9] have started assessing the potential application of the peptide to "coral seeding," by collecting coral larvae after mass spawning events and producing primary polyps or infant colonies for the purpose of transplantation and the subsequent restoration of coral reefs.

\section{Conclusions}

The role of peptides as important signal molecules in the development and physiology of primitive metazoans, such as Hydra, has long been recognized. In this paper, we described those GLWamide-family peptides that have been identified and isolated from sea anemones and hydra over the course of the Hydra Peptide Project that was initiated by us as a systematic peptide screening project to identify novel peptide molecules involved in regulation of development and physiological processes in Hydra [3]. These peptides have been shown to induce metamorphosis in both Hydractinia and Acropora planula larvae, and they also exhibit myoactivity in both hydra and sea anemone. While these peptides appear to be multifunctional, it is not apparent from the effects of the peptides in the same species. In addition, specific receptors of GLWamide-family peptides, such as Hym-248, have not yet been identified. Recently, the ability with which genes encoding peptide receptors, particularly GPCRs, has been greatly enhanced by the Hydra EST Project [24] and sequencing of the Hydra genome [25]. By mining these databases, it is hoped that specific GPCR receptors will be found in the near future.

It is well known that GLWamide-related peptides are present in higher metazoans, and GLWamide-like immunoreactivity has been observed in the cell bodies of neurons and in thin varicose fibers in some regions of rat brain [26]. These results strongly suggest that the rat nervous system contains as yet unidentified GLWamide-like peptides. Regarding the likely function of these peptides, the distribution patterns of GLWamide-positive fibers are similar to those of substance $\mathrm{P}$, which is considered to be an important neuropeptide in the processing of nociceptive information [26]. Taken together, these findings imply that rat GLWamide-like peptides are involved in sensory mechanisms, possibly those related to nociception. The search for authentic mammalian GLWamide-like peptides is currently in progress.

Finally, we also discussed potential applications of the GLWamide-family peptides. For example, GLWamide-family peptides appear to occur in a variety of animal taxa, ranging from mammals to cnidarians. One such application is the use of Hym-248 to produce "coral seedlings" which can then be transplanted and used for reef restoration. Other potential applications include the development of novel drugs that exploit the GLWamide motif to treat nociceptive pain in the mammalian brain.

\section{References}

[1] C. N. David, "A quantitative method for maceration of hydra tissue," Wilhelm Roux Archiv für Entwicklungsmechanik der Organismen, vol. 171, no. 4, pp. 259-268, 1973.

[2] T. Leitz, K. Morand, and M. Mann, "Metamorphosin A: a novel peptide controlling development of the lower metazoan Hydractinia echinata," Developmental Biology, vol. 163, no. 2, pp. 440-446, 1994.

[3] T. Takahashi, Y. Muneoka, J. Lohmann et al., "Systematic isolation of peptide signal molecules regulating development in hydra: LWamide and PW families," Proceedings of the National Academy of Sciences of the United States of America, vol. 94, no. 4, pp. 1241-1246, 1997.

[4] T. Takahashi, O. Koizumi, Y. Ariura et al., "A novel neuropeptide, Hym-355, positively regulates neuron differentiation in Hydra," Development, vol. 127, no. 5, pp. 997-1005, 2000.

[5] S. Yum, T. Takahashi, O. Koizumi et al., "A novel neuropeptide, Hym-176, induces contraction of the ectodermal muscle in Hydra," Biochemical and Biophysical Research Communications, vol. 248, no. 3, pp. 584-590, 1998.

[6] H. Shimizu and T. Fujisawa, "Peduncle of Hydra and the heart of higher organisms share a common ancestral origin," Genesis, vol. 36, no. 4, pp. 182-186, 2003.

[7] E. Hayakawa, T. Takahashi, C. Nishimiya-Fujisawa, and T. Fujisawa, "A novel neuropeptide (FRamide) family identified by a peptidomic approach in Hydra magnipapillata," FEBS Journal, vol. 274, no. 20, pp. 5438-5448, 2007.

[8] K. Carstensen, K. L. Rinehart, I. D. McFarlane, and C. J. P. Grimmelikhuijzen, "Isolation of Leu-Pro-Pro-Gly-ProLeu-Pro-Arg-Pro-NH2 (Antho-RPamide), an N-termally protected, biologically active neuropeptide from sea anemones," Peptides, vol. 13, no. 5, pp. 851-857, 1992.

[9] M. Hatta and K. Iwao, "Metamorphosis induction and its possible application to coral seedlings production," in Recent Advances in Marine Science and Technology, N. Sexena, Ed., pp. 465-470, Japan International Science and Technology Federation, Akasaka, Tokyo, Japan, 2002.

[10] K. Iwao, T. Fujisawa, and M. Hatta, "A cnidarian neuropeptide of the GLWamide family induces metamorphosis of reefbuilding corals in the genus Acropora," Coral Reefs, vol. 21, no. 2, pp. 127-129, 2002.

[11] P. M. Erwin and A. M. Szmant, "Settlement induction of Acropora palmata planulae by a GLW-amide neuropeptide," Coral Reefs, vol. 29, no. 4, pp. 929-939, 2010.

[12] T. Takahashi, Y. Kobayakawa, Y. Muneoka et al., "Identification of a new member of the GLWamide peptide family: physiological activity and cellular localization in cnidarian polyps," Comparative Biochemistry and Physiology B, vol. 135, no. 2, pp. 309-324, 2003.

[13] R. von Eggelkraut-Gottanka and A. G. Beck-Sickinger, "Biosynthesis of peptide hormones derived from precursor sequences," Current Medicinal Chemistry, vol. 11, no. 20, pp. 2651-2665, 2004.

[14] I. Leviev, M. Williamson, and C. J. P. Grimmelikhuijzen, "Molecular cloning of a preprohormone from Hydra magnipapillata containing multiple copies of Hydra-LWamide (LeuTrp- $\mathrm{NH}_{2}$ ) neuropeptides: evidence for processing at Ser and Asn residues," Journal of Neurochemistry, vol. 68, no. 3, pp. 1319-1325, 1997.

[15] B. A. Marcum and R. D. Campbell, "Development of hydra lacking nerve and interstitial cells," Journal of Cell Science, vol. 29, pp. 17-33, 1978. 
[16] R. D. Campbell, "Elimination of Hydra interstitial and nerve cells by means of colchicine," Journal of Cell Science, vol. 21, no. 1, pp. 1-13, 1976.

[17] T. Leitz and M. Lay, "Metamorphosin A is a neuropeptide," Roux's Archives of Developmental Biology, vol. 204, no. 4, pp. 276-279, 1995.

[18] J. Schmich, R. Rudolf, S. Trepel, and T. Leitz, "Immunohistochemical studies of GLWamides in Cnidaria," Cell and Tissue Research, vol. 294, no. 1, pp. 169-177, 1998.

[19] E. Espinoza, M. Carrigan, S. G. Thomas, G. Shaw, and A. S. Edison, "A statistical view of FMRFamide neuropeptide diversity," Molecular Neurobiology, vol. 21, no. 1-2, pp. 35-56, 2001.

[20] O. Hoegh-Guldberg, "Climate change, coral bleaching and the future of the world's coral reefs," Marine and Freshwater Research, vol. 50, no. 8, pp. 839-866, 1999.

[21] A. Huppert and L. Stone, "Chaos in the Pacific's Coral reef bleaching cycle," American Naturalist, vol. 152, no. 3, pp. 447459, 1998.

[22] R. C. Babcock, G. D. Bull, P. L. Harrison et al., "Synchronous spawnings of 105 scleractinian coral species on the Great Barrier Reef," Marine Biology, vol. 90, no. 3, pp. 379-394, 1986.

[23] T. Hayashibara, K. Shimoike, T. Kimura et al., "Patterns of coral spawning at Akajima Island, Okinawa, Japan,” Marine Ecology Progress Series, vol. 101, no. 3, pp. 253-262, 1993.

[24] T. Fujisawa, E. Hayakawa, and T. Takahashi, "Systematic identification of peptide signaling molecules by combining Hydra peptide and EST projects," in Peptide Chemistry, Y. Shimohigashi, Ed., pp. 21-24, Protein Research Foundation, 2004.

[25] J. A. Chapman, E. F. Kirkness, O. Simakov et al., "The dynamic genome of Hydra," Nature, vol. 464, no. 7288, pp. 592-596, 2010.

[26] K. Hamaguchi-Hamada, Y. Fujisawa, O. Koizumi, Y. Muneoka, N. Okado, and S. Hamada, "Immunohistochemical evidence for the existence of novel mammalian neuropeptides related to the Hydra GLW-amide neuropeptide family," Cell and Tissue Research, vol. 337, no. 1, pp. 15-25, 2009. 

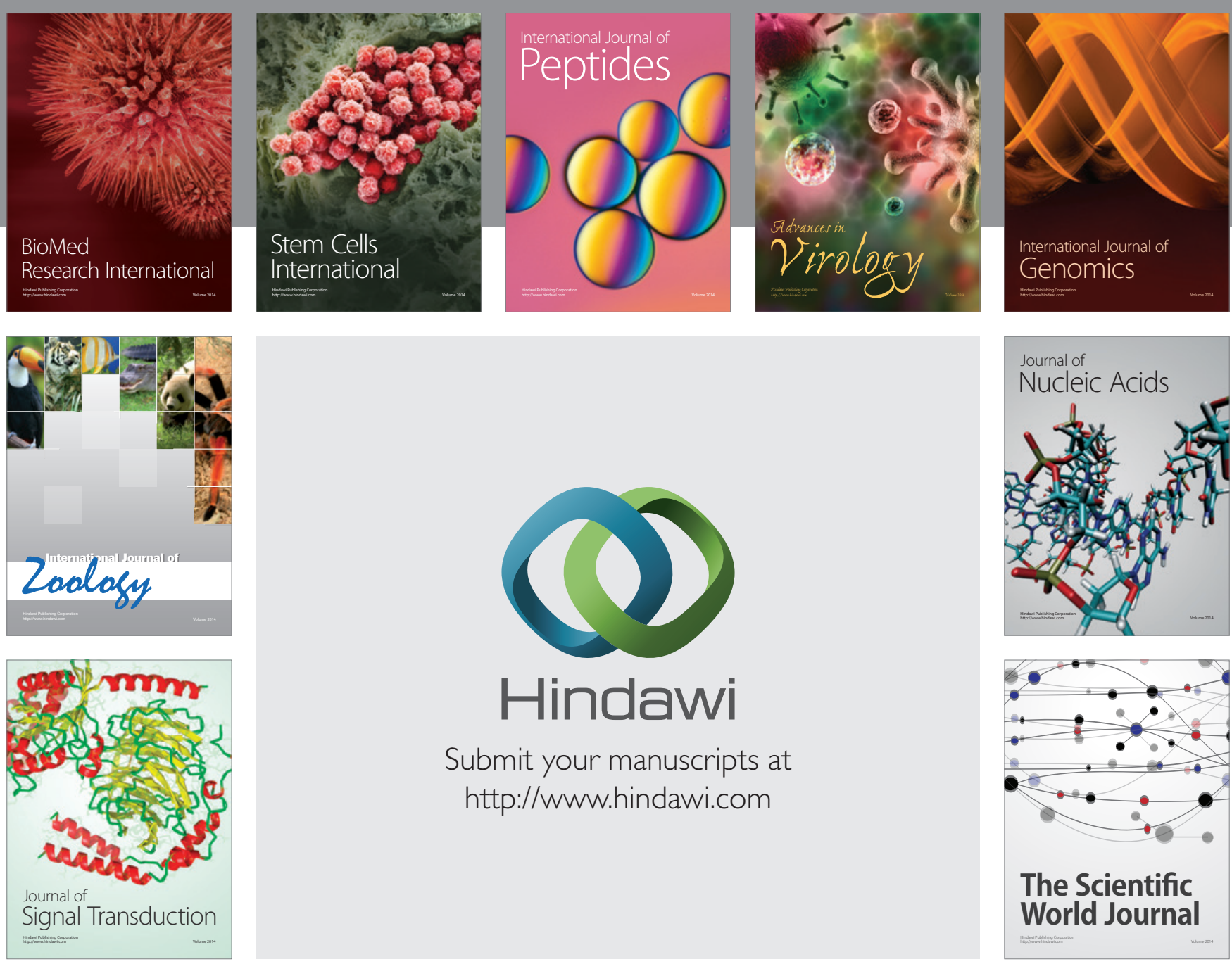

Submit your manuscripts at

http://www.hindawi.com
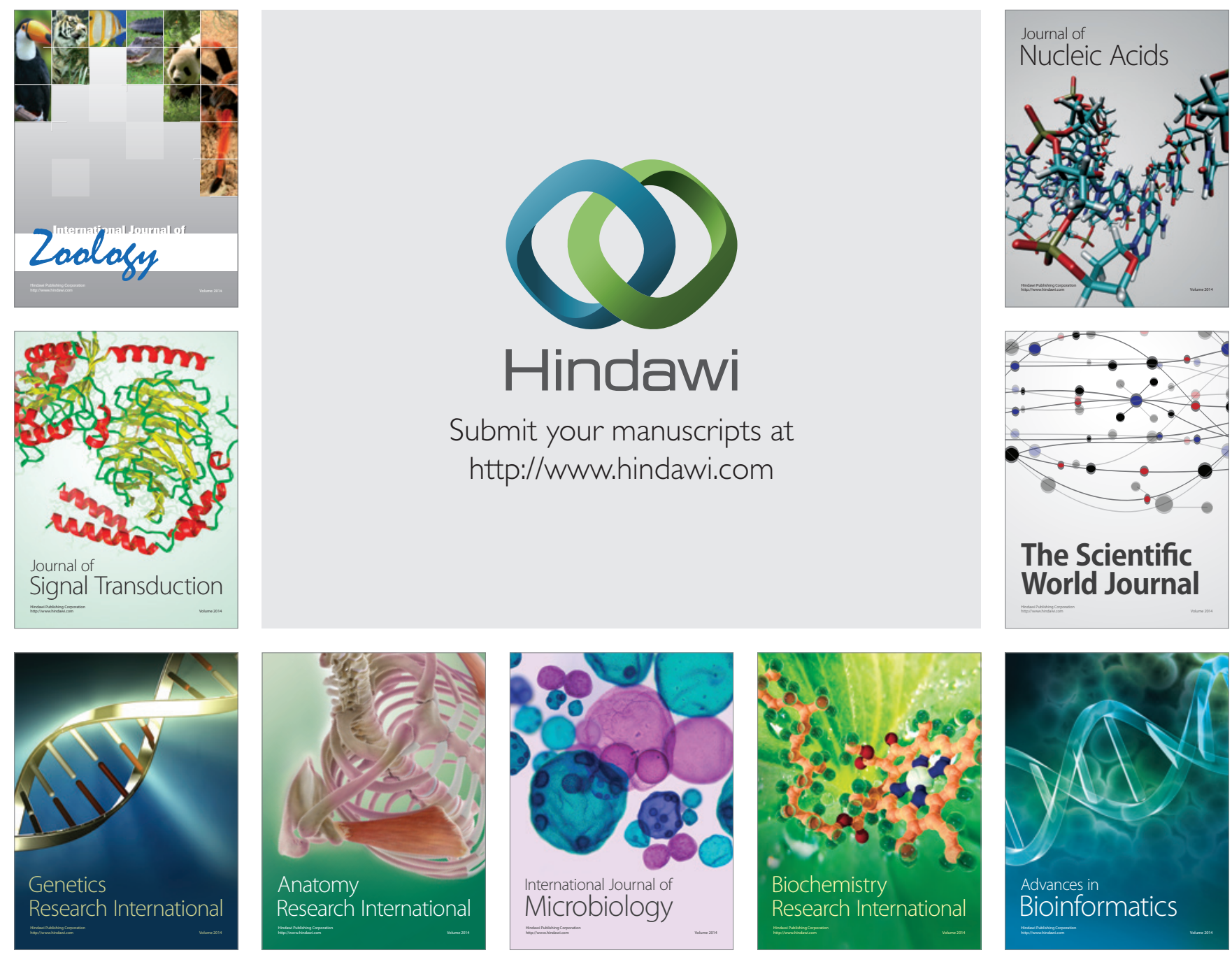

The Scientific World Journal
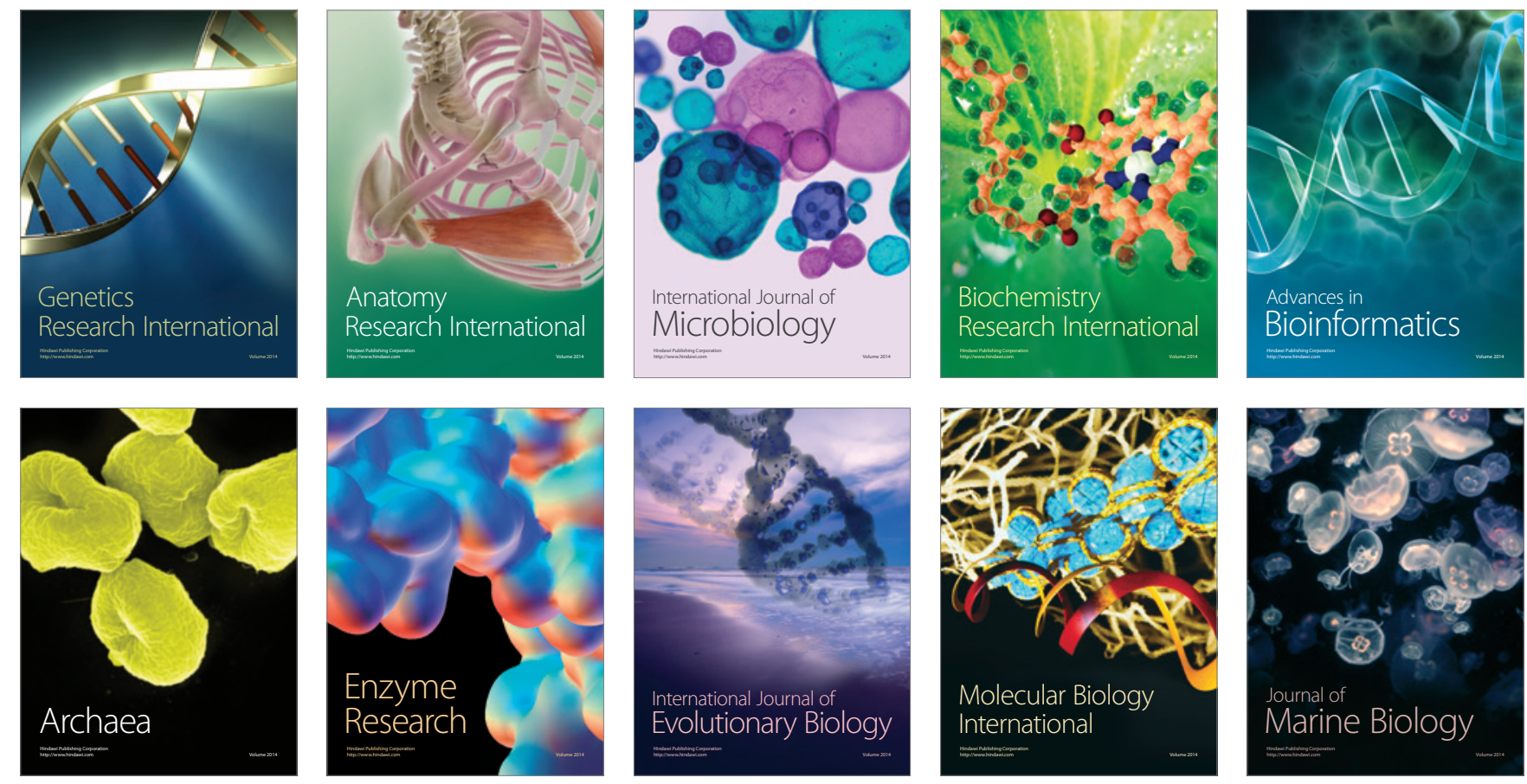